\title{
Öğretmen Adayları Gözünden Sonsuzluk Kavramı ve Matematik Dersi Öğretim
}

\section{Programı*}

\section{Özkan ERGENE**}

Öz: Doğası gereği algılanması zor olan sonsuzluk kavramı, öğrenciler tarafından zor olarak ifade edilmekte, kavramın öğrenim-öğretim süreçlerinde birtakım güçlükler yaşanmaktadır. Bununla birlikte sonsuzluk kavramının matematik öğretim programında ve öğretmen yetiştirme programında yeterince yer almadığı görülmüştür. Ülkemizde de matematik öğretim programlarında sonsuzluk kavramının sezgisel olarak yer aldığı belirtilmektedir. $\mathrm{Bu}$ araştırmada sonsuzluk kavramının ortaokul matematik öğretim programındaki yerinin öğretmen adayları gözünden incelenmesi amaçlanmıştır. Nitel araştırma yöntemi ile yürütülen araştırmanın deseni durum çalışması olarak belirlenmiştir. Araştırmanın çalışma grubunu uygun örnekleme yöntemi ile seçilen son sınıfta öğrenim gören 61 matematik öğretmen adayı oluşturmaktadır. Araştırma verileri yazılı görüş formu ve yarı yapılandırılmış görüşmeler aracılığıyla toplanmıştır. Araştırmada sonsuzluğun öğretim programlarında yer aldığı düşüncesi öğretmen adaylarının gözünden belirlenen kazanımlar ve açıklamalar ile ortaya konulmuştur. Öğretmen adayları matematik dersi öğretim programında beşinci, altıncı, yedinci ve sekizinci sınıf seviyelerinde yer alan 30 kazanımı sonsuzluk kavramı ile ilişkilendirmişlerdir. Sonsuzluk kavramı ile en fazla ilişkilendirilen kazanımların sayı kümeleri, örüntü ve irrasyonel sayılar konularına ait olduğu görülmüştür. Öğretmen adayları sonsuzluk kavramına yönelik bilgilerinin eksik olduğunu vurgulamışlar ve sonsuzluğun önemi noktasında farkındalık oluşturduklarını belirtmişlerdir. Ayrıca öğretmen adaylarının sonsuzluğun öğretim süreci hakkında yeterli bilgiye sahip olmadıkları görülmüştür.

Anahtar Kelimeler: Sonsuzluk, Matematik Dersi Öğretim Programı, Öğretmen Adayı

\footnotetext{
${ }^{*}$ Bu çalışma 2. Uluslararası Fen, Matematik, Girişimcilik ve Teknoloji Eğitimi Kongresi’nde (FMGTEK-2) sözlü bildiri olarak sunulan “Ortaokul Matematik Öğretim Programında Sonsuzluk Kavramı” adlı çalışmanın genişletilmiş halidir.

** Arş. Gör. Dr. Sakarya Üniversitesi, Eğitim Fakültesi, Matematik ve Fen Bilimleri Eğitimi Bölümü, Matematik Eğitimi Ana bilim Dal1, e-mail: ozkanergene@sakarya.edu.tr Orcid No: 0000-0001-5119-2813
}

\begin{tabular}{lll}
\hline Gönderim:01.02.2021 & Kabul:07.06.2021 & Yayın:26.09.2021
\end{tabular}




\section{The Concept of Infinity and Mathematics Lesson Curriculum from the Perspectives of}

\section{Pre-service Teachers}

Abstract: The concept of infinity, which is difficult due to its nature, is seen as a difficult concept by students, and some difficulties are experienced in the learning and teaching processes of this concept. In addition, it has been observed that the concept of infinity is not sufficiently included in the mathematics curriculum and in the teacher education program. It is asserted that the concept of infinity takes place intuitively in the Turkish mathematics curriculum. In this study, it was aimed to examine the place of the concept of infinity in the mathematics curriculum from the perspective of pre-service teachers. With this aim, qualitative research method was adopted, and the research design of the study was a case study. The participants of the study consisted of 61 pre-service mathematics teachers who were senior students at the time of the study, and they were selected by the convenience sampling method. Data were collected through a written questionnaire and semi-structured interviews. In the study, the fact that infinity is included in the curriculum has been revealed with the objectives determined from the perspective of the pre-service teachers and their explanations. The preservice teachers associated 30 objectives in $5^{\text {th }}, 6^{\text {th }}, 7^{\text {th }}$, and $8^{\text {th }}$ grade levels in the mathematics curriculum with the concept of infinity. It has been observed that the objectives which were most associated with infinity belong to the concepts of number sets, patterns, and irrational numbers. The pre-service teachers emphasized that they lacked knowledge regarding the concept of infinity and stated that they gained awareness about the importance of infinity. Furthermore, it was observed that the pre-service teachers did not have sufficient knowledge regarding the teaching process of infinity.

Keywords: Infinity, Mathematics Curriculum, Pre-service Teachers

\section{Giriş}

“Sonsuzluk” günlük hayatta sonu ve sınırı olmayan uzay, sonu olmayan gelecek zaman ve ebediyet anlamlarında kullanılmaktadır (Türk Dil Kurumu, 2020). Bununla birlikte sonsuzluk kavramı matematik, felsefe gibi birçok disiplin alanında araştırmacılar tarafından yüzyıllardır ilgi ile takip edilmektedir. Matematiksel anlamda sonsuzluk ise Bolzano, Dedekind, Cantor gibi ünlü matematikçilerin katkıları ile şekillense de günümüzde halen tartışılmaktadır (Tsamir ve Dreyfus, 2002). Devam eden bu tartışmaların ve sonsuzluğun doğası gereği (Kolar ve Cadez, 2012) öğrenme-öğretme süreçlerinde sezgisel ve kavramsal anlama bağlamında 
güçlükler içeren bir kavram olduğu düşüncesini de beraberinde getirmektedir. Bu düşünceyi sonsuzluk kavramı ile ilgili yapılan çalışmalar da desteklemektedir (Khasawneh, 2020).

Alan yazın incelendiğinde, ilköğretim ve ortaöğretim öğrencilerinin (Aztekin, 2008; Bozkuş ve diğerleri, 2015; Monaghan, 2001; Singer ve Voica, 2003), öğretmen adaylarının (Çaylan-Ergene ve Ergene, 2020; Çelik ve Akşan, 2013; Kolar ve Cadez, 2012) ve öğretmenlerin (Çaylan-Ergene ve Ergene, 2020; Maria ve diğerleri, 2009) sonsuzluk ile ilgili becerilerinin, algılarının ve düşüncelerinin ortaya konduğu araştırmaların olduğu görülmektedir. Yapılan araştırmalarda sonsuzluğa ilişkin öğrenim ve öğretim süreçlerinde güçlüklerin (eksik-hatalı öğrenmelerin ya da kavram yanılgılarının) olduğu belirlenmiştir (Aztekin, 2008; Kolar ve Cadez, 2012; Monaghan, 2001). Sonsuzluğun sezgisel anlamları (Pala ve Narlı, 2001; Tall, 2001), sonsuz kümelerin yapısı (Singer ve Voica, 2003; Tsamir ve Tirosh, 1999), sonsuzluk sembolü (Monaghan, 1986; 2001) gibi ifadeler kavramın anlamlandırılmasına ilişkin güçlüklerin nedenleri olarak görülmektedir.

Sonsuzluk kavramının anlamlandırılmasında sezgisel ve formal bilgi dengesinin kurulması gerekmektedir. Öğrencilerin sonsuzluk kavramı ile ilgili formal öğrenimlerine başlamadan önce sezgisel olarak sahip oldukları kavrayışlar bulunmaktadır (Özmantar, 2016). Bu kavrayışlar çoğu zaman formal öğrenmenin önüne geçerek sonsuzluğun hatalı ya da eksik anlamlandırılmasına neden olmaktadır (Singer ve Voica, 2003). Jirotkova ve Littler (2004) sezgisel olarak aktarılan sonsuzluk kavramının öğretiminin sonsuzluğun formal olarak öğrenilmesi noktasında eksiklik oluşturabileceğini belirtmiştir. Sonsuzluk kavramının anlamlandırılmasında deneyim eksikliğinden kaynaklı zihinde var olan sonlu şemalar ile kavramın doğası örtüşmemekte ve bunun sonucunda çelişkili durumlar ortaya çıkmaktadır (Fischbein, 2001; Fischbein ve diğerleri, 1979; Tall, 2001). Sezgisel olarak sonsuzun sürekli artan, sayılamaz ve çok büyük (Fischbein, 1987; Singer ve Voica, 2003) anlamları kavramla ilgili sorunlar yaşanmasına neden olmaktadır. Örneğin sonsuzluğun sürekli arttığı düşüncesi (Sbaragl1, 2006); eksi sonsuzun varlığı (Singer \& Voica, 2003) ya da $(0,1)$ aralığında yer alan birim kesirlerin sayısı gibi soruların doğru cevaplandırılması sürecinde çeşitli problemler teşkil edebilir. Öğrencilerin sonsuzluk kavramının sürekli arttı̆̆ını ve sınırlı bir bölgede sonsuzluktan bahsedilemeyeceğini düşünmeleri onların sıfır ile bir arasında sınırlı sayıda kesir vardır cevabını vermelerine neden olabilir. George Cantor tarafından ortaya konulan kümelerin denkliğini temel alan küme teorisi sonsuzluğun matematiksel bir nesne olarak görülmesine olanak sağlamıştır (Tsamir ve Dreyfus, 2002). Sonsuz kümelerin karş1laştırılamayacağı düşüncesi (Güven ve Karataş, 2004; Jirotkiva ve Littler, 2003; Pala, 2020; Tsamir, 2001) 
sonsuzluk kavramı ile ilgili yaşanılan bir güçlük olarak görülmektedir. Ayrıca sonsuz kümelerin karşılaştırılmasında parça-bütün vurgusu (Singer ve Voica, 2003) ve sonsuz tektir düşüncesi (Tsamir ve Tirosh, 1999) güçlüklerin oluşmasına neden olmaktadır. Doğal sayılar ile çift doğal sayılar kümesinin karşılaştırılmasında kümelerin büyüklüğünün belirlenmesi, ya da karşılaştırılamaz düşünceleri bu duruma örnek olarak gösterilebilir. Sonsuzluk sembolüne yüklenen "sonsuzun sayı olarak algılanması" kavrama ilişkin güçlüklerin başka bir nedeni olarak gösterilebilir (Nesin, 2002). Örneğin $\infty+1=\infty$ eşitliğinin anlamlandırılmasında sembol vurgusu bu duruma örnek olarak gösterilebilir.

Alan yazın incelendiğinde irrasyonel sayı, seri, limit, integral gibi birçok kavramın öğrenme-öğretme sürecinde sonsuzluk kavramının doğasından kaynaklanan güçlüklerin olduğu belirtilmektedir. Örneğin, limit kavramının içerisinde sonsuzluğu barındırması ve $n \rightarrow \infty$ ifadesi öğrencilerin limiti anlamasını engelleyebilecek durumlara örnek olabilir (Özmantar ve Yeşildere, 2016). Öğrenciler limit alma işleminde $n \rightarrow \infty$ ifadesini anlamakta güçlük çekmektedirler. Belirli integralin anlamlandırılmasında sonlu toplamlardan sonsuz toplamlara geçiş aşamasında, bir bölgenin sonsuz küçük parçaya ayrılması sürecinde sonsuzluk kavramından kaynaklı kavramsal anlama bağlamında sorunlar yaşandığı görülmüş̧ür (Ergene, 2019). Sonsuzluk kavramına yönelik eksik bilgiler, belirli integralin alt-üst Riemann toplamları ile ifadesini anlamayı güçleştirmektedir. "Sonsuz terimlerin sonsuz toplamı ifade ettiği” algısı (Bagni, 2000; 2008) ya da serilerin raksaklığı ve serilerin toplamı ile sonsuzluğun ilişkilendirilmesi (Ergene ve Özdemir, 2020) seri kavramı için örnek olarak verilebilir. Ayrıca irrasyonel sayıların sayı doğrusunda gösterilemeyeceği düşüncesine neden olan olası durumlardan bir tanesi sonsuzluk kavramı ile ilişkilidir (Çaylan-Ergene ve Ergene, 2020). Bu bağlamda sonsuzluk kavramının hem kendisinden kaynaklı hem de ilişkili olduğu kavramlarda ortaya çıkardığı güçlükler düşünüldüğünde kavramın soyut, öğrenilmesi zor ve zaman alan bir kavram olduğu vurgulanabilir. Sonsuzluğun kendisinden ve ilişkili olduğu kavramlardan kaynaklı güçlükler, sonsuzluğun öğrenimi ve öğretimi üzerinde durulmasını ve öğretim programlarındaki yerinin incelenmesinin önemli olduğuna işaret etmektedir.

\section{Sonsuzluk Kavramı ve Matematik Dersi Öğretim Programı}

Sonsuzluk kavramının öğretmen yetiştirme programında yeterince yer almadığ1 vurgulanmaktadır (Kattou ve diğerleri, 2010; Yopp ve diğerleri, 2011). Ülkemizde Yüksek Öğretim Kurulu [YÖK] tarafından 2018 yılında güncellenen Yeni Öğretmen Yetiştirme Lisans Programları çerçevesinde İlköğretim ve Ortaöğretim Matematik Öğretmenliği Programı’nda 
yer alan dersler ve içerikleri incelendiğinde (YÖK, 2018a; YÖK 2018b) sonsuzluk kavramı bir başlık olarak bulunmamaktadır. Sadece Ortaöğretim Matematik Öğretmenliği Programı'nda Soyut Matematik 2 dersinde sonlu ve sonsuz kümeler konusu yer almaktadır. 2018 yılında güncellenerek eğitim fakültelerinde yürütülen programın içeriği önceki programlar ile sonsuzluk kavramı açısından benzerlik göstermektedir. Sonsuzluk kavramının öğretimine ilişkin matematik dersi öğretim programlarında (MEB, 2018) ya da ders kitaplarında da yeteri kadar bilgiye yer verilmediği ve sonsuzluk kavramının sezgisel olarak yer aldığı belirtilmektedir (Bozkuş ve diğerleri, 2015; Özmantar, 2016). Ayrıca sonsuzluğun matematik öğretim programında yeterince yer almadığı, öğrencilere sonsuzluk kavramını nasıl ele almaları gerektiğinin yeterince aktarılmadığı, kavramın öğrencilere sezdirilmeye çalışıldığı ya da matematiksel olarak karşılığının verilmediği ifade edilmektedir (Monaghan, 1986, 2001). Matematiksel olarak sonsuzluk kavramı öğretim programlarında sayılar, örüntüler, seriler, limit, integral gibi birçok konu ya da kazanımlar ile dolaylı olarak öğretenlerin ve öğrenenlerin karşısına çıkmaktadır.

Öğretim programlarında sonsuzluk kavramının yer alması gerekliliği konusuna vurgu yapılmaktadır (Güven ve Karataş, 2004; Özmantar, 2016). Sezgisel olarak öğrencilere hissettirilen sonsuzluk kavramının ileri seviyelerde öğrenciler tarafından anlaşıldı̆̆ varsayılarak yeni kavramların öğretimine devam edilmesi sorunlara yol açmaktadır (Özmantar, a.g.e). Sonsuzluk kavramının doğası, kavramdan kaynaklı güçlükler ve kavramın öğretim programlarındaki yeri düşünüldüğünde, bu kavram ve öğretim süreci arasında nasıl öğretileceği, nasıl ele alınacağına ilişkin bir boşluk olduğu görülebilir. Uzun yıllardır ilgi ile takip edilen ve araştırmalara konu olan sonsuzluk kavramının öğrenim ve öğretim aşamalarında zihinlerde soru işaretlerinin olduğu ve bu soru işaretlerinin giderilmesi için bu bağlamda araştırmalar yapılması gerekliliği düşünülmektedir. Hatta sonsuzluk kavramı ilköğretimden yükseköğretim düzeyine kadar öğrencilerde neredeyse hiçbir öğretmen müdahalesi olmaksızın şekillenmektedir (Pala, 2020). Sonsuzluk kavramı için öğrenenlerin anlamlı öğrenme çıktılarını oluşturmaları, öğretmenlerin uygun bireysel öğretim tercihlerine sahip ve donanımlı olması ile mümkündür (Pala ve Narl1, 2018). Bu araştırmada da geleceğin öğretmenleri olacak matematik öğretmen adaylarının gözünden sonsuzluk kavramının ortaokul matematik öğretim programındaki [OMÖP] yerinin incelenmesi amaçlanmıştır. $\mathrm{Bu}$ amaç doğrultusunda “sonsuzluk öğretim programında yer almalı mı?” sorusu çerçevesinde öğretmen adayları gözünden öğretim programında sonsuzluk ile ilişkili olabileceği düşünülen kazanımlar 
incelenmiştir. Araştırma benzer özellikler gösteren iki çalışma grubu ile iki öğretim döneminde yürütülmüş ve aşağıdaki araştırma sorularına cevap aranmıştır.

i. Matematik öğretmeni adayları tarafından sonsuzluk kazanımı ile ilişkilendirilen kazanımların öğrenme alanları ve konulara göre dağılımı nasıldır ve ÇG ${ }_{1}$ 'e ve ÇG 'ye göre nasıl farkl11ık göstermektedir?

ii. Matematik öğretmeni adaylarının sonsuzluk kavramının öğretimine yönelik ve OMÖP’te sonsuzluk kavramı hakkındaki düşünceleri nelerdir ve çalışma gruplarına göre nasıl farkl1lık göstermektedir?

\section{Yöntem}

$\mathrm{Bu}$ araştırmanın amacına uygun olarak nitel araştırma yöntemi ile yürütülmesi planlanmıştır. Araştırmanın deseni iç içe geçmiş tekli durum çalışması (Yin, 2018) olarak belirlenmiştir. Durum çalışması, bir veya birden fazla durumun ya da olayın birden çok veri toplama kaynağı kullanarak keşfedildiği ve betimlendiği araştırma yaklaşımıdır (Creswell, 2003). Bu araştırmada da matematik öğretmeni adayları tarafından OMÖP’teki sonsuzluk kavramı ile ilişkilendirilen kazanımlar ile öğretmen adaylarının sonsuzluk kavramının öğretim süreci hakkındaki düşünceleri birer durum olarak belirlenmiştir. Araştırmada bu durumlar birlikte değerlendirilerek sonsuzluk kavramının OMÖP’teki yerinin öğretmen adayları gözünden incelenmesi amaçlanmıştır.

\section{Çalışma Grubu}

Araştırmanın çalışma grubunu uygun örnekleme yöntemi ile seçilen Marmara bölgesinde yer alan bir devlet üniversitesinde öğrenim gören 61 matematik öğretmeni adayı oluşturmaktadır. Araştırmanın verileri toplandığı esnada öğretmen adaylarının 31 tanesi (birinci çalışma grubu [ÇG 1 ]) 2019-2020 eğitim öğretim yılının 8. yarıyılında, kalan 30 tanesi ise (ikinci çalışma grubu [ÇG $\left.{ }_{2}\right]$ ) 2020-2021 eğitim öğretim yılının 7. yarıyılında öğrenim görmektedirler. ÇG '’in ve ÇG ${ }_{2}$ 'nin seçilmesinin nedeni, sonsuzluk kavramı ile ilişkilendirilen kazanımların benzerlik gösterip göstermeyeceğinin belirlenmesidir. ÇG $G_{1}$ 'de ve ÇG $G_{2}$ 'de yer alan öğretmen adaylarının tamamı Analiz I, Analiz II ve Analiz III derslerinde sonsuzluk ile ilişskili kavramları görmüşler, Özel Öğretim Yöntemleri I ve Özel Öğretim Yöntemleri II derslerinde alan eğitimi hakkında bilgi sahibi olmuşlar, Okul Deneyimi ve Öğretmenlik Uygulaması I derslerinde okul ortamında bulunmuşlardır. Ayrıca Öğretmenlik Uygulaması I dersini çalışma grubunda yer alan öğretmen adaylarının tamamı ve Öğretmenlik Uygulaması 
II dersini ise ÇG ${ }_{1}$ 'de yer alan öğretmen adayları almışlardır. ÇG ${ }_{1}$ 'de ve ÇG $G_{2}$ 'de yer alan öğretmen adaylarının tamamına araştırmacı tarafından yürütülen Matematiksel Kavramlar dersinde sonsuzluk kavramına iki ders saatinde değinilmiştir. Bu derste sonsuzluğun tarihsel gelişimi, sonsuzluk çeşitleri ve sonsuzluk ile ilişkili kavramlar aktarılmıştır. Çalışma grubunda yer alan öğretmen adayları sonsuzluk ile ilgili konu başlığı altında bir ders görmemişler; sadece sayılar, seriler, integral, diziler gibi kavramların öğrenimi sırasında sonsuzluk kavramı ile karşılaşmışlardır. Araştırmanın verilerinin benzer özelliklere sahip iki çalışma grubundan elde edilmesi ilişkilendirilen kazanımların ve düşüncelerin karşılaştırılmasına olanak sağlamıştır. Araştırma sürecinde ÇG $_{1}$ 'de ve ÇG ${ }_{2}$ 'de yer alan öğretmen adayları her bir grup için ayrı ayrı ÖA $A_{1}, \mathrm{ÖA}_{2} .$. şeklinde kodlanmıştır.

\section{Veri Toplama Süreci}

Araştırmanın verileri iki aşamada toplanmıştır. Çalışma grubuna öncelikle yazılı olarak sonsuzluk kavramına yönelik bilişsel davranışları yoklayan bir görüş formu verilmiştir. Ardından OMÖP ve sonsuzluk kavramına ilişkin düşüncelerini belirleyebilmek amacı ile yarı yapılandırılmış görüşmeler yapılmıştır. Veri toplama araçlarına ilişkin bilgilendirme Tablo 1 'de verilmiştir.

\section{Tablo 1.}

Veri Toplama Araçlarında yer alan sorular

Veri Toplama Aracı Sorular

Görüş Formu

Yarı Yapılandırılmış

Görüşmeler
- Matematik dersi öğretim programını (5.-8. Sınıflar) inceleyiniz. Öğretim programında sonsuzluk kavramının gömülü olduğu konu(lar) ve kazanım(lar) var mıdır? Var ise belirtiniz (Birden fazla kazanım belirtebilirsiniz)

- Belirlediğiniz kazanımın(ların) neden sonsuzluk kavramı ile ilişkili olabileceğini açıklayınız.

- Matematik dersi öğretim programında (5.-8. Sinıflar) sonsuzluk kavramı sizce yer almalı mı? (Evet-HayırKararsızım)

- Matematik dersi öğretim programını (5.-8. Sınıflar) incelemeden önce ve sonra sonsuzluk kavramı ile ilişkili 
düşüncelerinizde değişiklik oldu mu? Cevabınızı nedenleri ile açıklayınız.

- Sonsuzluk kavramının da gömülü olduğu kazanımları anlatma konusunda kendinizi yeterli görüyor musunuz?

Görüş formu ve yarı yapılandırılmış görüşmeler araştırma amacına uygun olarak hazırlanmıştır. Görüş formunda öğretmen adaylarının sonsuzluk kavramı ile OMÖP’te yer alan kazanımları ilişkilendirmeleri ve bu kazanımları ilişsilendirme nedenlerinin belirlenmesi amaçlanmıştır. Yarı yapılandırılmış görüşmelerde ise öğretmen adaylarının OMÖP'ü incelemelerinin sonsuzluk kavramı ile ilgili düşüncelerine olan etkisinin belirlenmesi amaçlanmıştır. Öğretmen adaylarına öğretim programını incelemeleri için üç haftalık bir süre verilmiştir. Görüş formu ve yarı yapılandırılmış görüşmelerde yer alan sorular yardımıyla sonsuzluk kavramının öğretim programında yer alması ve öğretim süreci hakkında öğretmen adaylarının düşüncelerinin belirlenmesi hedeflenmiştir. Görüş formunun alınmasından iki hafta sonra görüşmeler gerçekleştirilmiştir.

Araştırmada ÇG,'den elde edilen veriler 2019-2020 eğitim öğretim yılının bahar döneminde yüz yüze eğitim sürecinde, ÇG_'den elde edilen veriler 2020-2021 eğitim öğretim yılının güz döneminde uzaktan eğitim sürecinde toplanmıştır. Araştırmada amacı bağlamında iki grup üzerinden verilerin toplanması, sonsuzluk kavramına yönelik öğretmen adayı düşüncelerinin karşılaştırılmasına da imkân vermektedir. Çalışma gruplarında yer alan öğretmen adayları aynı öğretim programına tabi tutulmuş, aynı dersleri almışlardır. Öğretmen adayları gönüllülük esasına dayanarak araştırmaya katılmışlardır.

\section{Veri Analizi}

Araştırmadan elde edilen veriler betimsel analiz yardımıyla analiz edilmiştir. Öğretmen adaylarının sonsuzluk ile ilişkilendirdiği kazanımlar öncelikle beşinci, altıncı, yedinci ve sekizinci sınıf düzeylerine göre incelenmiş, ardından OMÖP’te yer alan sayılar ve işlemler, cebir, geometri ve ölçme, olasılık öğrenme alanlarına ve bu öğrenme alanlarında bulunan konulara göre aktarılmıştır. Kazanımları belirten öğretmen adaylarının kodları verilmiş ve frekanslar hesaplanmıştır. Yarı yapılandırılmış görüşmelerden elde edilen veriler için kategoriler oluşturulmuştur. Kategoriler oluştururken öncelikle öğretmen adaylarının ifadeleri bütüncül olarak incelenmiştir. Ardından benzer düşünceler gruplandırılmıştır. Birinci ve ikinci görüşme sorularında öğretmen adaylarının ifadeleri ikişer kategori altında toplanmıştır. Birinci 
görüşme sorusu için sonsuzluk kazanım ilişkisi ve sonsuzluk kavramının önemi kategorileri, ikinci kazanım için sonsuzluğa yönelik tespitler ve öğretim sürecine yönelik tespitler kategorileri oluşturulmuştur. Oluşturulan kategoriler öğretmen adayı ifadelerine yönelik açıklamalar ile aktarılmıştır.

\section{Araştırmanın Geçerlik ve Güvenirliği}

Nitel araştırma yöntemine göre planlanan çalışmalarda iç geçerlik ve dış geçerlik kavramları yerine inandırıcılık ve aktarılabilirlik kavramları kullanılmaktadır (Lincoln ve Guba, 1985). Bu araştırmada inandırıcılığın sağlanabilmesi amacıyla araştırmacı ile öğretmen adayları arasında etkileşim sağlanmış, her bir öğretmen adayı ile görüşmeler gerçekleştirilmiştir. Görüşmeler ÇG $_{1}$ 'de yer alan öğretmen adayları ile yüz yüze ofis ortamında, ÇG2' de yer alan öğretmen adayları ile Zoom ve Google Meet üzerinden çevrimiçi ortamda gerçekleştirilmiştir. Gerek görüş formunun uygulanma sürecinde gerek ise görüşmelerde öğretmen adayları ile açık ve rahat bir iletişim sağlanmıştır. Öğretmen adayları gönüllülük esasına dayanarak araştırmaya katılmışlardır. Araştırmanın sonsuzluk kavramına ilişkin benzer düşüncelere sahip olduğu düşünülen ve benzer eğitim sürecinden geçmiş iki farklı gruba uygulanarak elde edilen veriler arasında karşılaştırmalı analizlerin yapılmasına imkân sağlanmıştır. Ayrıca araştırmaya katılan öğretmen adaylarının özellikleri detaylı bir şekilde aktarılmıştır. Araştırmada veri toplama araçlarının oluşturulması, verilerin toplanması, analizi ve bulguların aktarım sürecinde matematik eğitimi alanında doktorasını tamamlamış bir uzmandan uzman görüşü alınmıştır. Araştırmanın verilerinin analizinde (birinci ve ikinci çalışma grubunun \%10'luk kısmına denk gelecek şekilde dörder tane olmak üzere) rastgele seçilen sekiz öğretmen adayının açıklamaları ve görüşme verileri bir matematik eğitimi uzmanı tarafindan analiz edilmiş ve analizler arasında birebir karşılaştırmalar yapılmıştır.

\section{Etik Kurul Kararı}

$\mathrm{Bu}$ araştırma için Sakarya Üniversitesi, Sosyal ve Beşerî Bilimler Etik Kurulu’ndan 13/01/2021 tarihli ve E.3540 sayı, 25 no'lu karar ile etik kurul uygunluk onayı alınmıştır.

\section{Bulgular}

Araştırmanın bulguları iki bölümde sunulmuştur. Birinci bölümde öğretmen adaylarının belirlediği kazanımlara ilişkin bulgulara, ikinci bölümde ise yarı yapılandırılmış görüşmelerden elde edilen bulgulara yer verilmiştir. Araştırmada iki grup üzerinden veriler 
toplanmıştır. Bu nedenle bulguların sunumunda bütüncül bir bakış açısı sunulacak ve çalışma grupları arasında karşılaştırmalar yapılacaktır.

\section{Öğretmen Adayları Tarafından Belirlenen Kazanımlar}

Çalışma grubunda yer alan öğretmen adayları tarafından sonsuzluk kavramı ile ilişkili 30 kazanım belirlenmiştir. Bu kazanımlardan 23 tanesi öğretmen adaylarının tamamı tarafından sonsuzluk kavramı ile ilişkilendirilmiştir. Kalan yedi kazanımdan beş tanesi sadece ÇG ${ }_{1}$ 'de yer

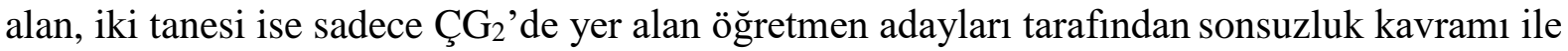
ilişkilendirilmiştir. Öğretmen adayları tarafından sonsuzluk kavramı ile ilişkili olduğu düşünülen kazanımlar sayılar ve işlemler, cebir, geometri ve ölçme ile olasılık öğrenme alanlarında farklı sınıf seviyelerinde 17 konu altında yer almıştır. Kazanımlardan dokuz tanesi beşinci sınıf, yedi tanesi altıncı sınıf, altı tanesi yedinci sınıf ve beş tanesi sekizinci sınıf seviyesindedir.

Beşinci sınıf seviyesinde sonsuzluk kavramı ile ÖMOP’te yer alan altı konu ve dokuz kazanım ilişkilendirilmiştir (Tablo 2). “Doğru, doğru parçası, 1şını açıklar ve sembolle gösterir." kazanımı 20 öğretmen adayı tarafından sonsuzluk ile en fazla ilişkilendirilen kazanım olmuştur. Bununla birlikte altı kazanım hem ÇG ${ }_{1}$ 'de hem de ÇG ${ }_{2}$ 'de yer alan öğretmen adayları tarafından, iki kazanım sadece ÇG ${ }_{1}^{\prime}$ de yer alan öğretmen adayları, bir kazanım ise sadece ÇG $_{2}$ ‘de yer alan bir öğretmen adayı tarafından sonsuzluk ile ilişkilendirilmiştir.

\section{Tablo 2.}

5. Sınıf düzeyindeki sonsuzluk ile ilişkilendirilen kazanımlar

\begin{tabular}{|c|c|c|c|c|}
\hline Konular & Kazanım & & - $C ̧ G_{1}$ & $\mathrm{CCG}_{2}$ \\
\hline $\begin{array}{l}\text { Doğal } \\
\text { Sayılar }\end{array}$ & M.5.1.1.3. & $\begin{array}{l}\text { Kuralı verilen sayı ve şekil } \\
\text { örüntülerinin istenen adımlarını } \\
\text { oluşturur. }\end{array}$ & $\mathrm{ÖA}_{4}$ & $\begin{array}{l}\mathrm{ÖA}_{12}, \mathrm{ÖA}_{21} \text {, } \\
\text { ÖA }_{28}\end{array}$ \\
\hline $\begin{array}{l}\text { Doğal } \\
\text { Sayılarla } \\
\text { İşlemler }\end{array}$ & M.5.1.2.3. & $\begin{array}{l}\text { Doğal sayılarla toplama ve } \\
\text { çıkarma işlemlerinin sonuçlarını } \\
\text { tahmin eder. }\end{array}$ & $\mathrm{ÖA}_{1}$ & \\
\hline \multirow[t]{2}{*}{ Kesirler } & M.5.1.3.4. & $\begin{array}{l}\text { Sadeleştirme ve geniş̧letmenin } \\
\text { kesrin değerini değiştirmeyeceğini } \\
\text { anlar ve bir kesre denk olan } \\
\text { kesirler oluşturur }\end{array}$ & $\mathrm{ÖA}_{5}, \mathrm{ÖA}_{6}$ & $\mathrm{ÖA}_{2}$ \\
\hline & M.5.1.3.1. & $\begin{array}{l}\text { Birim kesirleri sayı doğrusunda } \\
\text { gösterir ve siralar. }\end{array}$ & $\mathrm{ÖA}_{18}, \mathrm{ÖA}_{20}$ & $\begin{array}{l}\text { ÖA }_{6}, \mathrm{Ö}_{7}, \\
\text { ÖA }_{9}, \mathrm{ÖA}_{11} \\
\text { ÖA }_{12}\end{array}$ \\
\hline
\end{tabular}


Ondalık gösterimleri verilen

M.5.1.5.5. sayıları sayı doğrusunda gösterir $\quad$ ÖA $_{10}, \mathrm{Ö}_{12}$

Ondalık ve siralar.

Gösterim Ondalık gösterimleri verilen

M.5.1.5.6. sayılarla toplama ve çıkarma

işlemi yapar
ÖA 31
ÖA 23

$\mathrm{ÖA}_{3}, \mathrm{OA}_{4}$,

$\mathrm{ÖA}_{2}, \mathrm{ÖA}_{7}$

ÖA 6 , ÖA 13 ,

Temel

M.5.2.1.1.

Doğru, doğru parçası, 1şını açıklar ÖA $\mathrm{O}_{12}, \mathrm{OA}_{14}$,

ÖA $15, \mathrm{OA}_{16}$,

Geo. Kav. ve sembolle gösterir

ÖA $15, \mathrm{OA}_{16}$,

ÖA $19, \mathrm{OA}_{24}$,

ve

$\mathrm{Ö}_{17}, \mathrm{OA}_{21}$

$\mathrm{ÖA}_{25}, \mathrm{OA}_{26}$,

$\mathrm{OA}_{27}, \mathrm{OA}_{30}$

\section{Çizimler}

\section{Bir doğruya üzerindeki veya}

M.5.2.1.5. dişındaki bir noktadan dikme $\quad$ ÖA $22_{2}$ çizer.

\begin{tabular}{llll}
\hline $\begin{array}{l}\text { Üçgen ve } \\
\text { Dörtgenler }\end{array}$ & M.5.2.2.1. & $\begin{array}{l}\text { Çokgenleri isimlendirir, oluşturur } \\
\text { ve temel elemanlarını tanır. }\end{array}$ & ÖA \\
23 & $\mathrm{OA}_{29}$
\end{tabular}

Altıncı sınıf seviyesinde sonsuzluk kavramı ile OMÖP'te yer alan beş konu ve yedi kazanım ilişkilendirilmiştir (Tablo 3). Bu yedi kazanımın tamamı hem ÇG ${ }_{1}$ 'de hem de ÇG2'de yer alan öğretmen adayları tarafından sonsuzluk ile ilişkilendirilmiştir. "Tam sayıları tanır ve sayı doğrusunda gösterir." kazanımı ÇG ${ }_{1}$ 'de ve ÇG2'de yer alan toplamda 14 öğretmen adayı tarafindan sonsuzluk ile ilişkilendirilmiştir.

\section{Tablo 3.}

6. Sınıf düzeyindeki sonsuzluk ile ilişkilendirilen kazanımlar

\begin{tabular}{|c|c|c|c|c|}
\hline Konular & Kazanım & & $\mathrm{ÇG}_{1}$ & $\mathrm{ÇG}_{2}$ \\
\hline $\begin{array}{l}\text { Doğal } \\
\text { Sayılarla } \\
\text { İşlemler }\end{array}$ & M.6.1.1.2. & $\begin{array}{l}\text { Bir doğal sayının } \\
\text { kendisiyle tekrarlı } \\
\text { çarpımını üslü ifade olarak } \\
\text { yazar ve değerini hesaplar. }\end{array}$ & ÖA 9 , ÖA 30 & $\mathrm{ÖA}_{6}, \mathrm{ÖA}_{22}$ \\
\hline $\begin{array}{l}\text { Çarpanlar } \\
\text { ve Katlar }\end{array}$ & M.6.1.2.3. & $\begin{array}{l}\text { Asal sayıları özellikleriyle } \\
\text { belirler. }\end{array}$ & $\mathrm{ÖA}_{5}$ & $\begin{array}{l}\mathrm{ÖA}_{2}, \mathrm{Ö}_{8}, \mathrm{OA}_{17}, \\
\mathrm{ÖA}_{28}\end{array}$ \\
\hline \multirow[t]{2}{*}{ Tam Sayılar } & M.6.1.4.1. & $\begin{array}{l}\text { Tam sayıları tanır ve sayı } \\
\text { doğrusunda gösterir. }\end{array}$ & $\mathrm{ÖA}_{14}$ & $\begin{array}{l}\ddot{\mathrm{Ö}}_{1}, \mathrm{Ö}_{3}, \mathrm{Ö}_{5}, \mathrm{ÖA}_{7} \text {, } \\
\ddot{O ̈ A}_{9}, \mathrm{ÖA}_{14}, \mathrm{ÖA}_{17}, \\
\text { ÖA }_{19}, \text { ÖA }_{22}, \text { ÖA }_{24}, \\
\text { ÖA }_{26}, \mathrm{OA}_{27}\end{array}$ \\
\hline & M.6.1.4.2. & $\begin{array}{l}\text { Tam sayıları karşılaştırır, } \\
\text { sıralar. }\end{array}$ & $\mathrm{ÖA}_{16}$ & ÖA4, ÖA $16, \mathrm{ÖA}_{20}$ \\
\hline $\begin{array}{l}\text { Kesirlerle } \\
\text { İşlemler }\end{array}$ & M.6.1.5.1. & $\begin{array}{l}\text { Kesirleri karşılaştırır, } \\
\text { sıralar ve sayı doğrusunda } \\
\text { gösterir. }\end{array}$ & $\mathrm{ÖA}_{10}, \mathrm{ÖA}_{13}$ & $\mathrm{ÖA}_{16}, \mathrm{Ö}_{20}, \mathrm{ÖA}_{23}$ \\
\hline
\end{tabular}


Çember çizerek

M.6.3.3.1. merkezini, yarıçapını ve Ö $\mathrm{A}_{27} \quad$ ÖA $\mathrm{A}_{18}, \mathrm{Ö}_{30}$ çapını tanır.

Çember

Bir çemberin uzunluğunun

\begin{tabular}{|c|c|c|c|}
\hline M.6.3.3.2. & $\begin{array}{l}\text { çıpına oranının sabit bir } \\
\text { değer olduğunu ölçme } \\
\text { yaparak belirler. }\end{array}$ & $\mathrm{ÖA}_{24}$ & $\begin{array}{l}\mathrm{ÖA}_{8}, \mathrm{Ö}_{15}, \mathrm{ÖA}_{17} \\
\text { ÖA }_{20}, \text { ÖA }_{25}, \mathrm{ÖA}_{27}\end{array}$ \\
\hline
\end{tabular}

Yedinci sınıf seviyesinde sonsuzluk kavramı ile OMÖP’te yer alan üç konu ve altı kazanım ilişskilendirilmiştir (Tablo 4). "Rasyonel sayıları tanır ve sayı doğrusunda gösterir.” kazanımı ÇG ${ }_{1}$ 'de ve ÇG ${ }_{2}$ 'de yer alan toplamda 13 öğretmen adayı tarafından, "Sayı örüntülerinin kuralını harfle ifade eder, kuralı harfle ifade edilen örüntünün istenilen terimini bulur” kazanımı ise ÇG 'de ve ÇG ${ }_{2}$ ' de yer alan toplamda 10 öğretmen adayı tarafından sonsuzluk ile en fazla ilişskilendirilen kazanımlar olmuştur.

\section{Tablo 4.}

7. Sınıf düzeyindeki sonsuzluk ile ilişkilendirilen kazanımlar

\begin{tabular}{|c|c|c|c|c|}
\hline Konular & Kazanım & & $\mathrm{CCG}_{1}$ & $\mathrm{CSG}_{2}$ \\
\hline \multirow{3}{*}{$\begin{array}{l}\text { Rasyonel } \\
\text { Sayllar }\end{array}$} & M.7.1.2.3. & $\begin{array}{l}\text { Devirli olan ve olmayan ondalık } \\
\text { gösterimleri rasyonel sayı olarak } \\
\text { ifade eder. }\end{array}$ & $\begin{array}{l}\text { ÖA }_{13}, \text { ÖA }_{25} \text {, } \\
\text { ÖA }_{17}\end{array}$ & ÖA 15 \\
\hline & M.7.1.2.1. & $\begin{array}{l}\text { Rasyonel sayıları tanır ve sayı } \\
\text { doğrusunda gösterir. }\end{array}$ & $\begin{array}{l}\text { ÖA }_{28}, \text { ÖA }_{17} \text {, } \\
\text { ÖA } 19\end{array}$ & $\begin{array}{l}\ddot{O ̈ A}_{1}, \mathrm{ÖA}_{2}, \text { ÖA }_{5} \text {, } \\
\text { ÖA }_{7}, \ddot{O ̈ A}_{9} \\
\text { ÖA }_{14}, \mathrm{Ö}_{18} \text {, } \\
\text { ÖA }_{19}, \mathrm{ÖA}_{22} \text {, } \\
\text { ÖA }_{24}\end{array}$ \\
\hline & M.7.1.2.2. & $\begin{array}{l}\text { Rasyonel sayıları ondalık } \\
\text { gösterimle ifade eder }\end{array}$ & $\begin{array}{l}\text { ÖA }_{5}, \mathrm{Ö}_{10} \\
\text { ÖA }_{12} \mathrm{ÖA}_{16}, \\
\text { ÖA }_{18}, \text { ÖA }_{20}\end{array}$ & $\begin{array}{l}\text { ÖA }_{11}, \ddot{O A}_{13}, \\
\text { ÖA }_{15}\end{array}$ \\
\hline $\begin{array}{l}\text { Cebirsel } \\
\text { İfadeler }\end{array}$ & M.7.2.1.3. & $\begin{array}{l}\text { Sayı örüntülerinin kuralını harfle } \\
\text { ifade eder, kuralı harfle ifade } \\
\text { edilen örüntünün istenilen } \\
\text { terimini bulur. }\end{array}$ & $\begin{array}{l}\mathrm{ÖA}_{1}, \mathrm{Ö}_{2} \text {, } \\
\text { ÖA }_{6}, \mathrm{ÖA}_{8} \text {, } \\
\text { ÖA }_{13}\end{array}$ & $\begin{array}{l}\mathrm{O}_{3}, \mathrm{Ö}_{5} \\
\ddot{O}_{10}, \mathrm{ÖA}_{21}\end{array}$ \\
\hline \multirow{2}{*}{ Çokgenler } & M.7.3.2.1. & $\begin{array}{l}\text { Düzgün çokgenlerin kenar ve açı } \\
\text { özelliklerini açıklar. }\end{array}$ & $\mathrm{ÖA}_{1}$ & $\mathrm{ÖA}_{1}$ \\
\hline & M.7.3.3.3. & $\begin{array}{l}\text { Dairenin ve daire diliminin } \\
\text { alanını hesaplar }\end{array}$ & ÖA 11 & $\mathrm{ÖA}_{29}$ \\
\hline
\end{tabular}

Sekizinci sınıf seviyesinde sonsuzluk kavramı ile OMÖP’te yer alan beş konu ve sekiz kazanım ilişkilendirilmiştir. (Tablo 5). "Gerçek sayıları tanır, rasyonel ve irrasyonel sayılarla ilişkilendirir." ve "Birinci dereceden bir bilinmeyenli eşitsizlikleri sayı doğrusunda gösterir.” 
kazanımları hem ÇG ' $^{\prime}$ de hem de ÇG ${ }_{2}$ 'de yer alan toplamda yedişer öğretmen adayı tarafindan sonsuzluk ile en fazla ilişkilendirilen kazanımlar olmuştur.

Tablo 5.

8. Sınıf düzeyindeki sonsuzluk ile ilişkilendirilen kazanımlar

\begin{tabular}{|c|c|c|c|c|}
\hline Konular & Kazanım & & $\mathbf{C ̧ G}_{1}$ & $\mathbf{C S G}_{2}$ \\
\hline \multirow{3}{*}{$\begin{array}{l}\text { Kareköklü } \\
\text { İfadeler }\end{array}$} & M.8.1.3.2. & $\begin{array}{l}\text { Tam kare olmayan kareköklü bir } \\
\text { sayının hangi iki doğal sayı } \\
\text { arasında olduğunu belirler }\end{array}$ & $\mathrm{ÖA}_{13}$ & ÖA 29 \\
\hline & M.8.1.3.5. & $\begin{array}{l}\text { Kareköklü ifadelerde toplama ve } \\
\text { çıarma işlemlerini yapar. }\end{array}$ & $\mathrm{ÖA}_{3}, \mathrm{OA}_{7}$ & \\
\hline & M.8.1.3.8. & $\begin{array}{l}\text { Gerçek sayıları tanır, rasyonel ve } \\
\text { irrasyonel sayılarla ilişkilendirir. }\end{array}$ & ÖA 3 , ÖA 19 & $\begin{array}{l}\text { ÖA } A_{8}, \mathrm{Ö}_{13}, \\
\text { ÖA }_{14}, \ddot{O ̈}_{23} \text {, } \\
\text { ÖA }_{26}\end{array}$ \\
\hline \multirow[t]{2}{*}{$\begin{array}{l}\text { Doğrusal } \\
\text { denklemler }\end{array}$} & M.8.2.2.3. & $\begin{array}{l}\text { Aralarında doğrusal ilişki bulunan } \\
\text { iki değişkenden birinin diğerine } \\
\text { bağlı nasıl değiştiğini tablo ve } \\
\text { grafik ile gösterir. }\end{array}$ & $\mathrm{ÖA}_{22}$ & \\
\hline & M.8.2.2.4. & $\begin{array}{l}\text { Doğrusal denklemlerin grafiğini } \\
\text { çizer }\end{array}$ & ÖA $_{14}$ & $\mathrm{ÖA}_{4}, \mathrm{Ö}_{11}$ \\
\hline \multirow[t]{2}{*}{ Eşitsizlikler } & M.8.2.3.2. & $\begin{array}{l}\text { Birinci dereceden bir bilinmeyenli } \\
\text { eşitsizlikleri sayı doğrusunda } \\
\text { gösterir }\end{array}$ & $\mathrm{ÖA}_{14} \mathrm{ÖA}_{8}$ & $\begin{array}{l}\text { ÖA }_{18}, \ddot{O ̈}_{21}, \\
\text { ÖA }_{25}, \text { ÖA }_{28} \text {, } \\
\text { ÖA }_{30}\end{array}$ \\
\hline & M.8.2.3.3. & $\begin{array}{l}\text { Birinci dereceden bir bilinmeyenli } \\
\text { eşitsizlikleri çözer. }\end{array}$ & $\begin{array}{l}\mathrm{ÖA}_{6}, \mathrm{ÖA}_{7} \\
\text { ÖA }_{11}, \mathrm{ÖA}_{19}\end{array}$ & \\
\hline Olasılık & M.8.5.1.3 & $\begin{array}{l}\text { Eşit şansa sahip olan olaylarda her } \\
\text { bir çıtıtının olasılık değerinin eşit } \\
\text { olduğunu ve bu değerin } 1 / \mathrm{h} \\
\text { olduğunu açıklar }\end{array}$ & & $\mathrm{ÖA}_{10}$ \\
\hline
\end{tabular}

Öğretmen adaylarının sonsuzluk ile ilişkilendirdiği kazanımlar, öğrenme alanlarına ve konulara göre katılımcı sayısı ve kazanım sayısı bağlamında incelenmiştir (Tablo 6).

Tablo 6 incelendiğinde sayılar ve işlemler öğrenme alanında dokuz, cebir öğrenme alanında üç, geometri ve ölçme öğrenme alanında dört ve olasılık öğrenme alanında bir konuda yer alan kazanımlar çalışma grubunda yer alan öğretmen adayları tarafından sonsuzluk ile ilişkilendirilmiştir. Sayılar ve işlemler öğrenme alanında ÇG1'de yer alan öğretmen adayları 16 kazanımı; ÇG2'de yer alan öğretmen adayları ise 15 kazanımı sonsuzluk kavramı ile ilişkilendirmişlerdir. Toplamda ÇG1'de yer alan öğretmen adayları 25 kazanımı; ÇG2'de yer alan öğretmen adayları ise 28 kazanımı sonsuzluk kavramı ile ilişkilendirmişlerdir. 
Tablo 6.

Öğrenme alanlarına ve konulara göre sonsuzluk ile ilişkilendirilen kazanımlar

\begin{tabular}{|c|c|c|c|c|c|}
\hline \multirow[b]{2}{*}{$\begin{array}{l}\text { Öğrenme } \\
\text { Alanı }\end{array}$} & \multirow[b]{2}{*}{ Konular } & \multicolumn{2}{|c|}{$\mathbf{C ̧ G}_{1}$} & \multicolumn{2}{|r|}{$\mathbf{C ̧}_{2}$} \\
\hline & & $\begin{array}{c}\text { Kazanım } \\
\text { Sayısı }\end{array}$ & $\begin{array}{c}\text { İlişkilendiren } \\
\text { Öğretmen } \\
\text { Adayı }\end{array}$ & $\begin{array}{c}\text { Kazanım } \\
\text { Sayısı }\end{array}$ & $\begin{array}{c}\text { İlişkilendiren } \\
\text { Öğretmen } \\
\text { Adayı }\end{array}$ \\
\hline \multirow{10}{*}{$\begin{array}{l}\text { Sayılar ve } \\
\text { İşlemler }\end{array}$} & Doğal Sayılar & 1 & 1 & 1 & 3 \\
\hline & $\begin{array}{l}\text { Doğal Sayılarla } \\
\text { İșlemler }\end{array}$ & 2 & 3 & 1 & 2 \\
\hline & Kesirler & 2 & 4 & 2 & 6 \\
\hline & Kesirlerle İşlemler & 1 & 2 & 1 & 3 \\
\hline & Ondalık Gösterim & 1 & 1 & 2 & 3 \\
\hline & $\begin{array}{l}\text { Çarpanlar ve } \\
\text { Katlar }\end{array}$ & 1 & 1 & 1 & 4 \\
\hline & Tam Sayılar & 2 & 2 & 2 & 15 \\
\hline & Rasyonel Sayılar & 3 & 12 & 3 & 14 \\
\hline & Kareköklü İfadeler & 3 & 5 & 2 & 6 \\
\hline & Toplam & 16 & 31 & 15 & 56 \\
\hline \multirow{4}{*}{ Cebir } & Cebirsel İfadeler & 1 & 5 & 1 & 4 \\
\hline & $\begin{array}{l}\text { Doğrusal } \\
\text { Denklemler }\end{array}$ & 2 & 2 & 1 & 2 \\
\hline & Eşitsizlikler & 2 & 6 & 1 & 5 \\
\hline & Toplam & 5 & 13 & 3 & 11 \\
\hline \multirow{5}{*}{$\begin{array}{l}\text { Geometri } \\
\text { ve Ölçme }\end{array}$} & $\begin{array}{l}\text { Temel Geo. Kav. } \\
\text { ve Çizimler }\end{array}$ & 2 & 9 & 1 & 12 \\
\hline & $\begin{array}{l}\text { Üçgen ve } \\
\text { Dörtgenler }\end{array}$ & 1 & 1 & 1 & 1 \\
\hline & Çokgenler & 2 & 2 & 2 & 2 \\
\hline & Çember & 2 & 2 & 2 & 8 \\
\hline & Toplam & 5 & 5 & 5 & 11 \\
\hline Olasılık & Olasılik & 0 & 0 & 1 & 1 \\
\hline Toplam & & 28 & 58 & 25 & 91 \\
\hline
\end{tabular}

Sayılar ve işlemler öğrenme alanında rasyonel sayılar konusu, geometri ve ölçme öğrenme alanında temel geometrik kavramlar ve çizimler konusu, cebir öğrenme alanında ise eşitsizlikler konusu sonsuzluk kavramı ile en fazla ilişkilendirilen konular olmuştur. Olasılık öğrenme alanında sadece bir öğretmen adayı bir kazanımı sonsuzluk ile ilişkilendirmiştir.

\section{Belirlenen Kazanımların İlişkilendirmesine Yönelik Açıklamalar}

Çalışma grubunda yer alan öğretmen adaylarının belirledikleri kazanımların neden sonsuzluk kavramı ile ilişkili olduğuna ilişkin yaptıkları açıklamalar, kazanımın öğretim süreci, 
kazanıma ilişkin problem çözümleri, sonsuzluk kavramına ilişkin kavram yanılgıları ve sonsuzluk kavramına ilişkin düşüncelerin gelişimi kategorilerinde toplanmıştır (Tablo 7).

\section{Tablo 7.}

Sonsuzluk ile ilişkilendirilen kazanımların nedenlerine dair yapılan açıklamalar

\begin{tabular}{|c|c|c|c|c|c|}
\hline Kategori & Örnek Açıklamalar & $\mathbf{C ̧ G}_{1}$ & & $\mathbf{C ̧ G}_{2}$ & \\
\hline $\begin{array}{l}\text { Kazanımın } \\
\text { öğretim } \\
\text { süreci }\end{array}$ & $\begin{array}{l}\text { - Kazanımın öğretiminde sonsuzluk } \\
\text { kavramının ilişkili olduğu yerler } \\
\text { aktarılmalıdır. } \\
\text { - Kazanımın anlatılmasından önce } \\
\text { sonsuzluğun aktarılması gerekir. } \\
\text { - Sonsuzluk ile ilgili etkinlikler } \\
\text { yaptırılmalıdır. }\end{array}$ & $\begin{array}{l}\ddot{\mathrm{O}}_{5}, \\
\text { ÖA }_{9}, \\
\text { ÖA }_{12} \text {, } \\
\text { ÖA }_{22} \text {, } \\
\ddot{O}_{30} \text {, }\end{array}$ & $\begin{array}{l}\text { ÖA }_{8}, \\
\text { ÖA }_{10} \text {, } \\
\text { ÖA }_{14} \text {, } \\
\text { ÖA }_{26} \text {, } \\
\text { ÖA }_{31}\end{array}$ & $\begin{array}{l}\text { ÖA }_{1} \text {, } \\
\text { ÖA }_{4} \text {, } \\
\text { ÖA }_{14} \text {, } \\
\text { ÖA }_{29}\end{array}$ & $\begin{array}{l}\text { ÖA }_{3} \text {, } \\
\text { ÖA }_{12} \text {, } \\
\text { ÖA }_{27} \text {, }\end{array}$ \\
\hline $\begin{array}{l}\text { Kazanım } \\
\text { ile ilgili } \\
\text { problem } \\
\text { çözümleri }\end{array}$ & $\begin{array}{l}\text { - Kazanım ile ilişkili bazı soruların- } \\
\text { problemlerin çözümünde sonsuzluk } \\
\text { kavramının aktarılması gerekir. } \\
\text { - Sonsuzluk kavramı ögretilmez ise } \\
\text { kazanıma ilişkin soru çözümleri } \\
\text { eksik kalabilir. }\end{array}$ & $\begin{array}{l}\text { ÖA }_{2,} \\
\text { ÖA }_{15} \text {, } \\
\text { ÖA }_{18} \text {, } \\
\text { ÖA }_{27} \text {, }\end{array}$ & 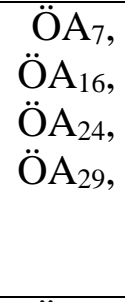 & $\begin{array}{l}\text { ÖA }_{5,} \\
\text { ÖA }_{10} \\
\text { ÖA }_{18} \\
\text { ÖA }_{24}\end{array}$ & $\begin{array}{l}\text { ÖA }_{8} \text {, } \\
\text { ÖA }_{15} \text {, } \\
\text { ÖA }_{21} \text {, }\end{array}$ \\
\hline $\begin{array}{l}\text { Sonsuzluk } \\
\text { kavramına } \\
\text { ilişkin } \\
\text { yanılgılar }\end{array}$ & $\begin{array}{l}\text { - Öğrenciler sonsuzluğun sürekli } \\
\text { arttığını düşünebilirler. } \\
\text { - Öğrenciler sonsuzluğun çok büyük } \\
\text { olduğunu düşünebilirler. } \\
\text { - Öğrenciler }(a, b) \text { aralığı içerisinde } \\
\text { sonsuzluk olmaz düşüncesine sahip } \\
\text { olabilirler. }\end{array}$ & $\begin{array}{l}\mathrm{ÖA}_{1}, \\
\text { ÖA }_{13}, \\
\text { ÖA }_{23}, \\
\text { ÖA }_{28} \text {, }\end{array}$ & $\begin{array}{c}\text { ÖA }_{4}, \\
\text { ÖA }_{20} \text {, } \\
\text { ÖA }_{25} \text {, }\end{array}$ & $\begin{array}{l}\text { ÖA }_{2,} \\
\text { ÖA }_{11}, \\
\text { ÖA }_{17}, \\
\text { ÖA }_{22} \text {, } \\
\text { ÖA }_{25} \\
\text { ÖA }_{28}\end{array}$ & $\begin{array}{l}\text { ÖA }_{7,} \\
\text { ÖA } \\
\text { ÖA }_{20}, \\
\text { ÖA }_{23}, \\
\text { ÖA }\end{array}$ \\
\hline $\begin{array}{l}\text { Sonsuzluk } \\
\text { kavramına } \\
\text { iliş̧kin } \\
\text { düşünceler } \\
\text { in gelişimi }\end{array}$ & 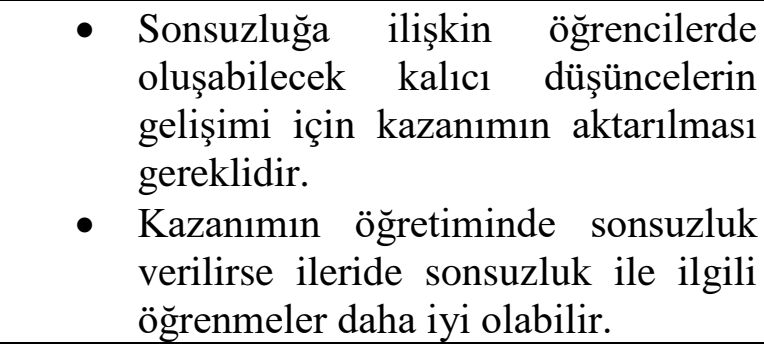 & $\begin{array}{l}\ddot{O} A_{3}, \\
\text { ÖA }_{11} \text {, } \\
\text { ÖA }_{19} \text {, }\end{array}$ & $\begin{array}{c}\text { ÖA }_{6}, \\
\text { ÖA }_{17} \text {, } \\
\text { ÖA }_{21} \text {, }\end{array}$ & $\begin{array}{l}\ddot{\mathrm{O}}_{6}, \\
\text { ÖA }_{13}, \\
\text { ÖA }_{30},\end{array}$ & $\begin{array}{c}\text { ÖA }_{9} \text {, } \\
\text { ÖA } A_{19}\end{array}$ \\
\hline
\end{tabular}

Tablo 7 incelendiğinde çalışma grubunda yer alan öğretmen adaylarının 17 tanesi kazanımın öğretim sürecine ilişkin; 17 tanesi ise kazanım ile ilgili problem çözümlerine ilişkin açıklamalarda bulunmuşlardır. Bununla birlikte öğretmen adaylarının 18 tanesi sonsuzluk kavramına ilişkin yanılgılar kategorisinde yer alan, öğretmen adaylarının 11 tanesi ise sonsuzluk kavramına ilişkin düşüncelerin gelişimi kategorisinde yer alan açıklamalarda bulunmuşlardır. Kazanımın öğretim sürecine ilişkin açıklama yapan öğretmen adayları; sonsuzluğun kazanımın anlatılmasının hemen öncesinde, kazanımın anlatıldığg anda ya da etkinlikler ile aktarılmasını gerektiğgine yönelik farklı açıklamalarda bulunmuşlardır. Kazanım 
ile ilgili problem çözümleri sürecinde sonsuzluğun aktarılmasını ifade eden öğretmen adayları problem çözümü yapılırken sonsuzluğun aktarılabileceğini belirtmişlerdir. Ayrıca sonsuzluk kavramının öğretilmediğinde kazanıma ilişkin soru çözümlerinin eksik kalabileceklerini belirtmişlerdir. Çalışma grubunda yer alan öğretmen adayları sonsuzluğun sürekli arttı̆̆ı, çok büyük olduğu gibi alan yazında da yer alan kavram yanılgılarının olabileceğini ifade etmişlerdir.

Görüş formunda yer alan "Matematik dersi öğretim programında (5.-8. Sınıflar) sonsuzluk kavramı yer almalı mıdır? sorusuna ilişkin öğretmen adaylarının 46 tanesi evet, altı tanesi hayır derken; yedi tanesi ise kararsız olduğunu belirtmiştir (Tablo 8).

\section{Tablo 8.}

Sonsuzluk kavramı öğretim programında yer almalı mıdır? sorusuna verilen cevaplar

\begin{tabular}{lllc}
\hline & ÇG $_{\mathbf{1}}$ & ÇG $_{\mathbf{2}}$ & Toplam \\
\hline Evet & 22 & 24 & 46 \\
\hline Hayır & 6 & 2 & 8 \\
\hline Kararsızım & 3 & 4 & 7 \\
\hline
\end{tabular}

\section{Yarı Yapılandırılmış Görüşmelerden Elde Edilen Bulgular}

Yarı yapılandırılmış görüşmelerde “OMÖP’ü incelemeden önce ve sonra sonsuzluk kavramı ile ilişkili düşüncelerinizde değişiklik oldu mu? Cevabınızı nedenleri ile açıklayınız.” sorusunda öğretmen adaylarının tamamı görüşlerinde değişiklik olduğunu ifade etmişlerdir. Öğretmen adaylarının bu görüşlerindeki değişikliklere neden olarak yaptıkları açıklamalar Tablo 9'da verilmiştir.

Tablo 9.

Sonsuzluk kavramı ile ilișkili öğretmen adayları düşünceleri

\begin{tabular}{|c|c|c|c|}
\hline Kategori & Örnek Açıklamalar & $\mathbf{C ̧ G}_{1}$ & $\mathbf{C ̧ G}_{2}$ \\
\hline \multirow{2}{*}{$\begin{array}{l}\text { Sonsuzluk } \\
\text { Kazanım } \\
\text { İlişkisi }\end{array}$} & $\begin{array}{l}\text { Sonsuzluk kavramının çok sayıda kazanım ile ilgili } \\
\text { olduğunu fark ettim. }\end{array}$ & 20 & 19 \\
\hline & $\begin{array}{l}\text { İlişkili olduğu kavramları kavramsal anlama } \\
\text { noktasında sonsuzluk kavramının bilinmesi gereklidir. }\end{array}$ & 21 & 24 \\
\hline $\begin{array}{l}\text { Sonsuzluk } \\
\text { Kavramının } \\
\text { Önemi }\end{array}$ & $\begin{array}{l}\text { Sonsuzluk kavramının düşündüğümden çok daha } \\
\text { önemli olduğunu fark ettim. } \\
\text { Sonsuzluk kavramının bilinmesi gereken bir kavram } \\
\text { olduğunu gördüm. }\end{array}$ & 26 & 21 \\
\hline
\end{tabular}


Tablo 9 incelendiğinde çalışma grubunda yer alan öğretmen adaylarının büyük çoğunluğunun OMÖP’te yer alan çok sayıda kazanım ile sonsuzluğun ilişkili olduklarına yönelik farkındalık oluşturdukları görülmüştür. Öğretmen adayları, sonsuzluk kavramının çok sayıda kazanım ile ilgili olduğunu yönelik görüş bildirmişlerdir. Bu duruma örnek olarak ÇG ${ }_{1}$ 'de yer alan ÖA 17 ile yapılan görüşmeden alınan bir kesit aşağıda verilmiştir. ÖA 17 ortaokul öğretim programını inceledikten sonra sonsuzluğa yönelik düşüncesinin değiştiğini ifade etmiştir.

ÖA17: Ortaokul matematik öğretim programını ilk kez incelemeye başladığımda açıkçası kazanım bulamayacağımı düşünmüştüm. Fakat zamanla çok sayıda kazanımın içerisinde sonsuzluğun olduğunu fark ettim...

Yapılan görüşmelerde katılımcılar sonsuzluk kavramının önemini fark ettiklerini ifade etmişlerdir. Öğretmen adayları sonsuzluk kavramının önemini fark ettiklerini ve sonsuzluğun bilinmesi/öğrenilmesi gereken bir kavram olduğunu düşündüklerini belirtmişlerdir. Bu duruma örnek olarak ÇG2'de yer alan ÖA 23 ile yapılan görüşmeden alınan bir kesit aşağıda verilmiştir. ÖA 23 açıklamasında sonsuzluk kavramına yönelik düşüncesinin değişimini ifade etmiştir.

ÖA23: Ortaokul matematik öğretim programını incelerken sonsuzluk konusunun düşündüğümden çok daha önemli olduğunu gördüm... Sonsuzluk ortaokulda, lisede hatta üniversitede tam olarak bize anlatılmadığı için bu kadar önemli görmemiştim. Hatta bu araştırmaya katılmasaydım belki de hiç fark etmeyecektim...

Bununla birlikte, öğretmen adayları sonsuzluğun bilinmesinin anlatılacak kazanımların kavramsal anlama noktasında katkı sağlayacağını belirtmişlerdir. Bu duruma örnek olarak ÇG ${ }_{1}$ 'de yer alan ÖA $A_{5}$ ile yapılan görüşmeden alınan bir kesit aşağıda verilmiştir. ÖA açıklamasını bir örnek ile zenginleştirmiş ve sonsuzluk vurgusunun yapılmaması durumunda kavramsal anlamanın eksik kalabileceğini belirtmiştir.

ÖA5: Anlatacağımız kazanımlarda yer alan konuları sadece işlem becerisi olarak değil de kavramsal olarak da öğretmemiz gerekir. Bu durumda sonsuzluk kavramı çok daha önemli.... Örneğin 6.Sınıf seviyesinde 100'e kadar asal olan sayılar gösterilmekte ve bu öğrenilen bilgi üzerine yeni bilgi konulamadan ortaokul sonlandırılmaktadır. Ortaöğretim öğretim programında da bu duruma ilişkin kesin bir ifade bulunmamaktadır. Fakat öğrencilere doğal sayılar, tam sayılar, rasyonel ve irrasyonel sayılar kümelerinin sonsuz küme olduğu hissettirildiği gibi asal sayılar kümesinin de sonsuz küme oluşunun hissettirilmesi önem taşımaktadır. Bu noktada asal sayılar ile ilgili sonsuzluk vurgusu yapılmazsa kavramsal anlama 
eksik kalabilir...

Yarı yapılandırılmış görüşmelerde "Sonsuzluk kavramının da gömülü olduğu kazanımları anlatma konusunda kendinizi yeterli görüyor musunuz?” sorusuna çalışma grubunda yer alan öğretmen adaylarının tamamı kendilerini bu noktada yetersiz hissettiklerini belirtmişlerdir. Öğretmen adayları bu durumun nedenleri olarak Tablo 10'da verilen açıklamaları ifade etmişlerdir.

\section{Tablo 10.}

Sonsuzluk kavramı ile ilişkili öğretmen adaylarının yeterlikleri hakkındaki açıklamaları

\begin{tabular}{|c|c|c|c|}
\hline Kategori & Örnek Açıklamalar & $\mathbf{C ̧ G}_{1}$ & $\mathbf{C S G}_{2}$ \\
\hline $\begin{array}{l}\text { Sonsuzluğa } \\
\text { Yönelik } \\
\text { Tespitler }\end{array}$ & $\begin{array}{l}\text { Sonsuzluk kavramına ilişkin bilgilerimi arttırmalıyım. } \\
\text { Sonsuzluk ile ilgili daha fazla araştırma yapmam } \\
\text { gerekliliğini hissettim. }\end{array}$ & 29 & 30 \\
\hline \multirow{2}{*}{$\begin{array}{l}\text { Öğretim } \\
\text { Sürecine } \\
\text { Yönelik } \\
\text { Tespitler }\end{array}$} & $\begin{array}{l}\text { Anlatacağım konu ve kazanımlardan önce } \\
\text { "sonsuzluk" kavramı ile ilişkili bilgilendirme } \\
\text { yapmalıyım. }\end{array}$ & 17 & 14 \\
\hline & $\begin{array}{l}\text { Nasıl bir yaklaşım göstereceğim ya da ne yapacağım } \\
\text { hakkında bir fikrim yok. }\end{array}$ & 14 & 16 \\
\hline
\end{tabular}

Tablo 10 incelendiğinde öğretmen adaylarının kendilerini yetersiz hissetme noktasında yaptıkları açıklamaların sonsuzluk kavramına yönelik ve öğretim sürecine yönelik tespitler olduğu görülmüştür. Öğretmen adaylarının neredeyse tamamının sonsuzluk kavramına yönelik var olan bilgilerini arttırmaları gerekliliğini ve daha fazla araştırma yapmaları gerekliliğini ifade ettikleri görülmüştür. Bu duruma örnek olarak ÇG ${ }_{2}$ 'de yer alan ÖA4 ile yapılan görüşmeden alınan bir kesit aşağıda verilmiştir.

ÖA4: "Sonsuzluk" kavramını bugüne kadar hep merak edip irdelemek istememe rağmen bu konunun gömülü olduğu konuları ve kazanımları anlatma konusunda kendimi yeterli görmüyorum. Sonsuzluğun çok derin bir kavram olduğunu düşünüyorum. $\mathrm{Bu}$ sebeple sonsuzluk kavramının tamamen anlaşılabilmesi için yeterli bilgiye sahip olmadığımı düşünüyorum. Bu nedenle sonsuzluk kavramına ilişkin bilgilerimi geliştirmem gerekliliğini düşünüyorum.

Öğretim sürecine yönelik yapılan tespitlerde öğretmen adaylarının 31 tanesi sonsuzluk kavramı ile ilişkili konu ve kazanımların anlatımından önce bilgilendirme yapmaları gerekliliğini ifade etmiştir. Bu duruma örnek olarak ÇG ${ }_{1}$ 'de yer alan ÖAs ile yapılan görüşmeden alınan bir kesit aşağıda verilmiştir 
ÖA8: "Kendi bilgi ve deneyimlerimin de "sonsuzluk" konusunda eksik olduğunu düşünüyorum. Derslerimde ise sonsuzluk ile ilgili ön bilgiler vermeliyim. Örneğin tam sayılar konusunu anlatırken sonsuzluğu dersten önce aktarmalıyım. "Sonsuzluk" kavramının öğretiminde günlük hayat örnekleriyle destekleyip öğrencilerin zihninde somutlaştırmalıyım.

Geriye kalan öğretmen adaylarının 30 tanesi ise bu noktada ne yapmaları gerektiği konusunda net bir düşüncelerinin olmadığını belirtmişlerdir. Bu duruma örnek olarak ÇG2'de yer alan Ö $\mathrm{A}_{21}$ ile yapılan görüşmeden alınan bir kesit aşağıda verilmiştir

ÖA21: Sonsuzluk kavramı ilkokuldan lisans eğitimime kadar öğrendiğimiz konu ve kazanımların kimisinde gizli kimisinde ise açıkça belli durumda olmasına rağmen "Sonsuzluk" kavramı ile ilgili daha önceden öğrendiğim konu ve kazanımlar doğrultusunda rahatça yorum yapabilme ya da herhangi bir araştırma yapmadan birbirinden farklı bakış açıları ile konuyu inceleme ve aktarma konusunda yeterince iyi bir noktada olduğumu düşünmüyorum. Sonsuzluk kavramının öğretimine ilişkin bir açıklama yapılmadığı ya da lisans eğitimimiz boyunca görmediğimiz için açıkçası ne yapabileceğimi şu aşamada çok bilmiyorum.

\section{Tartışma, Sonuç ve Öneriler}

Öğretmen adayları sonsuzluk kavramı ile OMÖP’te yer alan 30 kazanımı ilişskilendirmişlerdir. OMÖP’te 215 kazanımın yer aldığı düşünüldüğünde ilişkilendirilen kazanım sayısının öğretim programında yer alan kazanımların yaklaşık \%15'ine karşılık geldiği söylenebilir. Sonsuzluk ile ilişkilendirilen kazanımlar farklı sınıf seviyelerinde benzer sayılarda dağılmıştır. Bu durum her bir sınıf seviyesinde sonsuzlukla ilişkili kazanımların yer aldığının bir göstergesi olarak düşünülebilir. ÇG ${ }_{1}$ 'de ve ÇG ${ }_{2}$ 'de yer alan öğretmen adayları tarafından sonsuzluk ile ilişkilendirilen kazanım sayısının birbirine yakın olması kavramın öğretim programındaki ağırlığının farklı gruplar tarafından benzer şekilde belirlendiğinin bir göstergesi olarak görülebilir. Çalışma gruplarının benzer özellik gösterdiği için bu sonucun ortaya çıkabileceği düşünülebilir. Bu durum araştırmanın bir sınırlılığı olarak görülebilir. Bununla birlikte ilişkilendirilen kazanımların büyük çoğunluğunun ÇG ${ }_{1}$ 'de ve ÇG 'de yer alan öğretmen adayları tarafından ortak olarak belirlenmiştir. Bu noktada her ne kadar benzer özellik gösteren çalışma grupları olsa da sonsuzluk ile ilişkilendirilen kazanımların sayısı ve benzerliği sonsuzluğun gömülü olduğu düşünülen kazanımlara ilişkin fikir birliğinin oluştuğu ve bu kazanımların sayısının fazla olduğu şeklinde yorumlanabilir. 
Araştırmada, öğretmen adaylarının ÖMOP’te her bir sınıf seviyesinde farklı kazanımların sonsuzluk kavramı ile ilişkili olduğunu düşündükleri sonucuna ulaşılmıştır. Bu sonuç alan yazında matematik dersi öğretim programlarında sonsuzluk kavramının yer aldığı (Özmantar, 2016) düşüncesini de desteklemektedir. Tabi ki bu noktada öğretmen adaylarının düşünceleri ve belirledikleri kazanımlar neticesinde bu sonuca varıldığı belirtilmelidir.

Sonsuzluk kavramının gömülü olduğu düşünülen kazanımların yarısından fazlası sayılar ve işlemler öğrenme alanına aittir. Bununla birlikte kazanımların sırasıyla geometri ve ölçme, cebir ve olasılık öğrenme alanlarında yer alan konulara ait olduğu görülmüsstür. Bu durum OMÖP’te yer alan öğrenme alanlarına ait kazanım sayıları ile benzerlik göstermektedir. Öğretmen adaylarının belirli kazanımlar ile sonsuzluk kavramını daha çok ilişkilendirmeleri, kazanımlar bağlamında ilişkilendirme farklılıklarının olduğunu göstermektedir. Sayılar ve işlemler öğrenme alanında farklı sınıf seviyelerinde "Tam sayıları tanır ve sayı doğrusunda gösterir.”, "Rasyonel sayıları tanır ve sayı doğrusunda gösterir.”, "Gerçek sayıları tanır, rasyonel ve irrasyonel sayılarla ilişkilendirir.", ve "Birim kesirleri sayı doğrusunda gösterir ve sıralar.” kazanımlarının sonsuzluk kavramı ile ilişkilendirilmesi sayı kümelerinin sonsuzluğu düşüncesinin öğretim programında farklı kazanımlar ile var olduğunun göstergesi olarak görülebilir. Sayı kümelerinin sonsuzluğu hakkında ilköğretim (Narlı ve Narlı, 2012), ve ortaöğretim (Güven ve Karataş, 2004) öğrencilerinin yanılgılara sahip olması ÖMOP’te yer alan bu kazanımlar ile sonsuzluk kavramının ilişkilendirilmesi durumunu desteklemektedir. Ayrıca cebir öğrenme alanında "Sayı örüntülerinin kuralını harfle ifade eder, kuralı harfle ifade edilen örüntünün istenilen terimini bulur." kazanımının sonsuzluk kavramı ile en fazla ilişkilendirilen kazanım olması örüntü ve dizi konularında sonsuzluğun düşünüldüğünün bir göstergesi olabilir. Nitekim seri, dizi ve örüntü kavramlarını temel alan araştırmalarda kavramların anlamlandırılmasında sonsuzluk bir engel olarak görülmektedir (İşleyen, 2013; Ergene ve Özdemir, 2020). Bununla birlikte geometri ve ölçme öğrenme alanında "Doğru, doğru parçası, 1şını açıklar ve sembolle gösterir", "Çember çizerek merkezini, yarıçapını ve çapını tanır.”, kazanımlarının sonsuzluk kavramı ile en fazla ilişkilendirilen kazanımlar olması geometrik kavramların çizim süreçlerinde sonsuzluğun vurgulanması gerekliliği düşüncesinin bir göstergesi olarak yorumlanabilir. Ayrıca "Bir çemberin uzunluğunun çapına oranının sabit bir değer olduğunu ölçme yaparak belirler” kazanımı $\pi$ sayısının öğretim sürecinin detaylandırılması düşüncesi ile ilgili olabilir. Bu bağlamda araştırmanın ortaya koyduğu bir başka sonuç ise öğretmen adayları tarafından sonsuzluk ile en fazla ilişkilendirilen kazanımların sonsuzluktan kaynaklı güçlüklerin yaşandığı sayı kümeleri, örüntü, dizi, 
irrasyonel sayılar gibi kavramlar ile ilişkili olmasıdır. Matematik derslerinde herhangi bir kavram öğretimi öncesinde kavramın ön şartı olarak görülebilecek diğer kavramlar kazandırılması gerektiğinden (Altun, 2013) belirlenen kavramların öğretimi öncesinde sonsuzluk kavramının üzerinde durulması düşünülebilir.

Öğretmen adaylarının belirledikleri kazanımların neden sonsuzlukla ilişkili olduğuna yönelik yaptıkları açıklamalar, belirlenen kazanımın özelinde ya da sonsuzluk kavramı üzerinde yoğunlaşmaktadır. Bu kazanımlar ile ilgili soru ya da problemlerin çözümlerinde de sonsuzluğun önemli olduğu öğretmen adayları tarafından vurgulanmaktadır. Bu durum sonsuzluğun kendisinin ve ilişkili olan diğer kavramların aktarımında konu-kavram anlatımı ve soru-problem çözümü aşamalarında sonsuzluğun düşünülmesi gerekliliğinden kaynaklanabilir. Öğretmen adayları ile yapılan görüşmelerde sonsuzluk kavramına yönelik farkındalık oluşturdukları görülmüştür. Bu farkındalık, sonsuzluğun öğretim programında birçok kazanımla ilişkili olduğu, bu kazanımların kavramsal anlamasında sonsuzluğun belirleyici olduğu ve sonsuzluğun önemi noktalarında ortaya çıkmıştır. Sonsuzluk kavramına yönelik oluşan bu farkındalık ile öğretmen adaylarında farklı bakış açıları da oluşmuştur. Öğretmen adaylarının bir bölümü, belirledikleri kazanımların anlatılacağı derslerde öncelikle sonsuzluk ile ilgili bilgi vereceklerini ifade ederken, diğerleri ise bu konu hakkında ne yapacakları konusunda net bir yaklaşımlarının ya da bilgilerinin olmadığını ifade etmişlerdir. Bu durum sonsuzluğun öğretim sürecine yönelik öğretmen adaylarının eksik bilgiye sahip oldukları sonucunu ortaya koymaktadır. $\mathrm{Bu}$ durum, öğretmen yetiştirme programlarının sonsuzluk kavramından uzak olmasının (Katto ve diğerleri, 2010; Yopp ve diğerleri, 2011) olası bir sonucu olarak görülebilir. Öğretmen adayları sonsuzluğa yönelik bilgilerinin yeterli olmadığını vurgulamışlar ve bu konuda araştırma yapmaları gerekliliğini dile getirmişılerdir. Bu durumun sonsuzluğun anlamlandırılmasında yaşanılan güçlükler (Dreyfus ve Tsamir, 2004; Narl1, 2011; Tirosh ve Tsamir, 1996; Tsamir, 2001) ile benzerlik gösterdiği düşünülebilir. Çünkü öğretmen adaylarının sonsuzluğa yönelik eksik bilgileri kavramın anlamlandırılmasında oluşan güçlüklerin nedenlerinden biri olmaktadır. Araştırmanın bulguları ve sonuçları öğretmen adaylarının sonsuzluk kavramına yönelik sahip olduğu bilgiler çerçevesinde değerlendirilmelidir. Öğretmen adayları mezun olduktan sonra meslek hayatlarında bu kazanımları (sonsuzluk kazanımına yönelik mevcut bilgileri ile) öğrencilere aktaracaklardır. İlişkilendirilen kazanımların öğretimine yönelik düşünceler dikkate alınırken öğretmen adaylarının sonsuzluk kavramına yönelik eksik bilgilerinin de olduğu düşünülmelidir. $\mathrm{Bu}$ bağlamda mikro öğretimler ya da öğretmenlik uygulaması derslerinde belirlenen kazanımların 
(sonsuzluk kavramına yönelik farklı bilgi seviyesindeki) öğretmen adayları tarafından öğretim sürecine yönelik araştırmaların yapılması önerilebilir.

Sonuç olarak bu araştırmada sonsuzluğun OMÖP’te yer aldığı düşüncesi öğretmen adayları tarafından belirlenen kazanımlar ve öğretmen adaylarının yaptıkları açıklamalar ile ortaya konulmuştur. Tabi ki araştırmanın sadece öğretmen adayları tarafından belirlenen kazanımlar ve düşünceleri temelli ilerlediği göz ardı edilmemelidir. Kazanımların sonsuzluk kavramı ile ne derece ilişkili olduğunun belirlenmesi yapılacak yeni araştırmalar için bir öneri olarak sunulabilir. Bununla birlikte sonsuzluk ile ilişkili olduğu düşünülen kazanımların her iki çalışma grubu tarafından ortak olarak belirlenmesi, en fazla ilişkilendirilen kazanımların sonsuzluk ile ilgili alan yazında yer alan konulara ait güçlükler ile benzerlik göstermesi araştırmanın güçlü yönleri olarak ortaya konulabilir. Öğretmen adaylarının OMÖP ve sonsuzluk arasındaki ilişkiye yönelik farkındalık göstermeleri, sonsuzluk ile ilgili bilgi eksikliklerini ifade etmeleri de araştırmanın ortaya koyduğu önemli sonuçlar olarak görülebilir. Ayrıca öğretmen adaylarının sonsuzluğun öğretimi hakkında belirgin düşüncelerinin olmaması da dikkat çeken bir başka durumdur. Sonsuzluk ile ilgili yapılan çalışmalarda kavramın öğretim programında yer almasına ilişkin önerilerle sıklıkla karşılaşılmaktadır (Güven ve Karataş, 2004; Özmantar, 2016). Öğrenenler açısından anlamlı öğrenme çıktılarını oluşturmaları için öğretmenlerin uygun bireysel öğretim tercihlerine sahip ve donanımlı olması ile mümkün (Pala ve Narl1, 2018) olabileceği düşünüldüğünde, bu araştırmanın öğretmen adayları için bir farkındalık oluşturduğu ifade edilebilir.

Geleceğin matematik öğretmenlerinin sonsuzluk ve öğretim programı hakkındaki ifadelerini ve düşüncelerini ortaya koyan bu araştırma ile alan yazında yer alan bu önerilerin dikkate alınması gerekliliği yeniden vurgulanabilir. Son yıllarda ÖMOP’te yapılan sadeleştirmeler düşünüldüğünde sonsuzluğun öğretmen yetiştirme ve öğretim programlarında yer alması düşüncesinin nasıl gerçekleştirilebileceğini konu alan araştırmalar yapılması önerilebilir.

Öğretim programı hazırlama sürecinin karmaşık ve birçok değişkeni içeren bir süreç olduğu (Erdoğan ve diğerleri, 2019) ve programların konu ve kazanımların içeriği ve yapısı arasında uyuşmazlıklar ve çelişkiler oluşturduğu (Erdoğan, 2015) vurgulanmaktadır. Bu bağlamda hali hazırda Eğitim Fakülteleri öğretim programlarının güncellenme çalışmalarının olduğu düşünüldügüñnde program geliştiriciler ve matematik eğitimcilerinin sonsuzluk kavramının öğretmen yetiştirme ve öğretim programlarında bir konu başlığı olarak yer alması 
ve nasıl aktarılması düşüncelerini benimseyerek bu araştırmanın da sonuçlarını dikkate alarak tartışmalar yapması önerilebilir. Ayrıca öğretmen adayları ile yapılan bu çalışmanın öğretmenler ile de yapılması mevcut araştırmanın sonuçları ile karşılaştırılmasına olanak sağlayabilir. Araştırma bağlamında OMÖP’te yer alan başta sonsuz kümeler, örüntü ve irrasyonel sayılar olmak üzere kazanımların öğretim sürecinde anlatım, materyal ve etkinlik kullanımı, ders planı gibi durumların incelenmesini temel alan kavram temelli ya da kazanım temelli araştırmaların da yapılması önerilebilir.

\section{Makalenin Bilimdeki Konumu}

Matematik ve Fen Bilimleri Eğitimi Bölümü/ Matematik Eğitimi

\section{Makalenin Bilimdeki Özgünlüğü}

Matematik derslerinde sonsuzluk kavramının açık olarak tartışılmadığı ve kavrama yönelik doğrudan konu, kazanım ya da etkinlik olmadığı görülmektedir (Özmantar, 2016). Sonsuzluk kavramına ilişkin benzer bir durum öğretmen yetiştirme programlarında da söz konusudur. Sonsuzluk kavramının matematik öğretim programlarından uzak olduğu Monaghan (2001) tarafından ifade edilmiş, Özmantar (2016) da benzer düşünceleri vurgulamıştır. Günümüzde de halen benzer eleştirilerin yapılabileceği ve bu durumun sonsuzluk kavramının anlamlandırılmasına yönelik bir problem oluşturabileceği düşünülmektedir. Sonsuzluğun matematik öğretim programlarındaki varlığına yönelik bir bakış açısı oluşturmak amacıyla bu araştırmada OMÖP ve sonsuzluk kavramı geleceğin matematik öğretmenlerinin gözünden incelenmiştir. Matematik öğretmeni adaylarının sonsuzluk kavramı ile ilişkilendirdiği kazanımlar ve bu kazanımlar ile sonsuzluk kavramının öğretim sürecindeki düşünceleri ile bakış açısına yönelik değerlendirmelerin yapılabileceği düşünülmektedir.

\section{Kaynakça}

Altun, M. (2013). Ortaokullarda (5., 6., 7. ve 8. sınıflarda) matematik öğretimi. Bursa: Aktüel Yayınları.

Aztekin, S. (2008). Farklı yaş gruplarındaki öğrencilerde yapılanmış sonsuzluk kavramlarının araştırılması (Yayımlanmamış doktora tezi). Gazi Üniversitesi, Ankara.

Bagni, G. (2000). Difficulties with series in history and in the classroom, in History in Mathematics Education: The ICMI Study, J.F.J. Maanen, ed., Kluwer Academic Publishers, Dordrecht, The Netherlands, pp. 82-86. 
Bagni, G.T. (2008). A theorem and its different proofs: History, mathematics education and the semiotic-cultural perspective. Canadian Journal of Science, Mathematics and Technology Education, 8(3), 217-232.

Bozkuş, F., Toluk Uçar, Z. ve Çetin, İ. (2015). Ortaokul öğrencilerinin sonsuzluğu kavrayışları. Turkish Journal of Computer and Mathematics Education (TURCOMAT), 6(3), 506-531.

Creswell, J. W., (2003). Research design: Qualitative, quantitative, and mixed methods approaches ( $2^{\text {nd }}$ ed.). Thousand Oaks, CA: Sage.

Çaylan-Ergene, B. ve Ergene, Ö. (2020). Repeating decimals and irrational numbers on the number line: Through the lens of pre-service and in-service mathematics teachers. Acta Didactica Napocensia, 13(2), 215-232.

Çelik, D. ve Akşan, E. (2013). Matematik öğretmeni adaylarının sonsuzluk, belirsizlik ve tanımsızlık kavramlarına ilişkin anlamaları. Necatibey Eğitim Fakültesi Elektronik Fen ve Matematik Ĕ̈itimi Dergisi, 7(1), 166-190.

Erdoğan, A. (2015). Turkish primary school students' strategies in solving a non-routine mathematical problem and some implications for the curriculum design and implementation. International Journal for Mathematics Teaching and Learning,16, 1-27.

Erdoğan, A., Akkurt Denizli, Z. ve Çoban, F. N. (2019). Why some concepts cannot survive in mathematics curriculums? Example of perspective drawings. Elementary Education Online, 18(4), 1858-1874.

Ergene, Ö. (2019). Matematik öğretmeni adaylarının Riemann toplamlarını kullanarak modelleme yoluyla belirli integrali anlama durumlarının incelenmesi (Yayımlanmamış doktora tezi). Marmara Üniversitesi, İstanbul.

Ergene, Ö. ve Ahmet Şükrü, Ö. (2020). A study on the pre-service elementary mathematics teachers' knowledge on the convergence and divergence of series in the context of theoretical and application. Revista Latinoamericana de Investigación en Matemática Educativa, 23(2), 203-232.

Fischbein, E. (1987). Intuition in science and mathematics. Dodrecht, Holland: Reidel.

Fischbein, E. (2001). Tacit models and infinity. Educational Studies in Mathematics, 48(2-3), 309-329.

Fischbein, E., Tirosh, D. ve Hess, P. (1979). The intuition of infinity. Educational Studies in Mathematics 10(1), 3-40.

Güven, B. ve Karataş, İ. (2004). Sonsuz kümelerin karşılaştırılması: Öğrencilerin kullandıkları yöntemler. Dokuz Eylül Üniversitesi Buca Eğitim Fakültesi Dergisi, 15, 65-73 
Jirotková, D. ve Littler, G. (2004). Insight into pupils’ understanding of infinity in a geometrical context. Paper session presented at the meeting of Proceedings of the 28th Conference of the International Group for the Psychology of Mathematics Education, Bergen, Norway.

Kattou, M., Thanasia, M., Kontoyianni, K., Constantinos, C. ve George, P. (2010). Teachers' perceptions about infinity: a process or an object? Paper presented at the sixth congress of the European Society for Research in mathematics education, Lyon, France, 28 January1 February, 2009.

Khasawneh A. A. (2020). Analysis of infinity conceptions in mathematics among graduate, undergraduate and secondary Jordanian students. Psychology and Education. 57(2), 8490.

Kolar, V. M. ve Cadez, T. H. (2012). Analysis of factors influencing the understanding of the concept of infinity. Educational Studies in Mathematics, 80(3), 389-412.

Lincoln, Y. S. ve Guba, E. G. (1985). Naturalistic Inquiry. Newbury Park, CA: Sage Publications

Maria, K., Thanasia, M., Katerina, K., Constantinos, C. ve George, P. (2009). Teachers' perceptions about infinity: a process or an object? Proceedings of CERME 6 (28 January- 1 February, Lyon, France, ss.1771-1780).

Millî Eğitim Bakanlığg (MEB). (2018). Matematik dersi öğretim programı (İlkokul ve ortaokul 1, 2, 3, 4, 5, 6, 7 ve 8. sinıflar). Ankara: Millî Eğitim Bakanlığı.

Monaghan, J.D. (2001). Young peoples' ideas of infinity. Educational Studies in Mathematics, 48(2-3), 239-257.

Monaghan, J. (1986), Adolescents' Understanding of Limits and Infinity (Unpublished doctoral dissertation). Mathematics Education Research Centre, University of Warwick, UK

Nesin, A. (2002). Matematik ve sonsuz. 30.11.2020 tarihinde http://www.alinesin.org/popular_math/S_7_matematik_ve_sonsuz.doc adresinden erişilmiştir.

Özmantar, M. F. (2016). Sonsuzluk kavramı: Tarihsel gelişimi, öğrenci zorlukları ve çözüm Önerileri. M.F. Özmantar, E. Bingölbali ve H.Akkoç (Ed.). Matematiksel Kavram Yanılgıları ve Çözüm Önerileri (ss. 151-180) İçinde, (4.Baskı). Pegem Akademi.

Özmantar, M. F. ve Yeşildere, S. (2016). Limit ve süreklilik konularında kavram yanılgıları ve çözüm arayışları. M.F. Özmantar, E. Bingölbali ve H. Akkoç (Ed.). Matematiksel kavram yanılgıları ve çözüm önerileri (s. 181-221) İçinde, (4.Bask1). Pegem Akademi. 
YYÜ Ĕ̌itim Fakültesi Dergisi (YYU Journal of Education Faculty), 2021;18(2)123-151,http://efdergi.yyu.edu.tr,

Pala, O. (2020). İspat İmajının Dinamiklerinin Sonsuz Kümelerin Denkliği Bă̆lamında Incelenmesi (Yayınlanmamış Doktora tezi). Dokuz Eylül Üniversitesi, İzmir.

Pala, O. ve Narlı, S. (2018). Sonsuzluğun Tarihsel Gelişimi ve Öğretimi Üzerine. Apsistek, Ekim/2018.

Sbaragl1, S., (2006). Primary school teachers' beliefs and change of beliefs on mathematical infinity. Mediterranean Journal for Research in Mathematics Education, 5(2), 49-76

Singer, M. ve Voica, C. (2003). Perception of infinity: Does it really help in problem solving?. The Mathematics Education into the $21^{\text {st }}$ Century Project Proceedings of the International Conference.

Tall, D. O. (2001). Natural and formal infinities. Educational Studies in Mathematics, 48(2-3), 199- 238.

TDK Güncel Türkçe Sözlük. Tema. 11 Kasım 2020 tarihinde https://sozluk.gov.tr/ sayfasından erişilmiştir.

Tsamir, P. (2001). When 'the same' is not perceived as such: The case of infinite sets. Educational Studies in Mathematics, 48(2-3), 289-307.

Tsamir, P. ve Dreyfus, T. (2002). Comparing infinite sets- a process of abstraction: The case of Ben. Journal of Mathematical Behaviour, 21(1), 1-23.

Tsamir, P. ve Tirosh, D. (1999). Consistency and representations: The case of actual infinity. Journal for Research in Mathematics Education, 30(2), 213-219.

Yin, R. K. (2018). Case study research and applications. Design and methods, 6.ed. Sage publications.

Yopp, D. A., Burroughs, E. A. ve Lindaman, B. J. (2011). Why it is important for in-service elementary mathematics teachers to understand the equality $999 \ldots=1$. Journal of Mathematical Behavior, 30(4), 304-318.

YÖK. (2018a). İlköğretim Matematik Öğretmenliği Lisans Programı. 28.11.2020 tarihinde https://www.yok.gov.tr/kurumsal/idari-birimler/egitim-ogretim-dairesi/yeni-ogretmenyetistirme-lisans-programlari adresinden erişilmiştir.

YÖK. (2018b). Matematik Öğretmenliği Lisans Programı. 28.11.2020 tarihinde https://www.yok.gov.tr/kurumsal/idari-birimler/egitim-ogretim-dairesi/yeni-ogretmenyetistirme-lisans-programlariadresinden adresinden erişilmiştir. 


\section{Summary}

\section{Statement of Problem}

It is emphasized that the concept of infinity is not sufficiently included in the teacher education program (Yopp, Burroughs \& Lindaman, 2011). In addition, it has been observed that the concept of infinity is far from the mathematics curriculum (Monaghan, 2001) and the concept is perceived by students intuitively or is not given mathematically (Özmantar, 2010). When the literature is examined, it is realized that there are difficulties arising from the nature of the concept of infinity in the teaching and learning process of many concepts such as irrational number, series, limit, and integral. For example, during the transition from finite sums to infinite sums in the meaning of the definite integral, there were problems arising from the concept of infinity in the process of dividing a region into smaller parts (Ergene, 2019). The thought that "infinite terms express infinite sum" (Bagni, 2000) or the association of divergence of series with infinity in comparing the sum of a divergent series with a real number (Ergene \& Özdemir, 2020) can be given as examples for the concept of series. Furthermore, one of the possible situations that cause the thought that irrational numbers cannot be represented on the number line is related to the concept of infinity (Çaylan-Ergene \& Ergene, 2020). Jirotkova and Littler (2004) stated that there is a problem in teaching the concept of infinity, which is transferred intuitively. In addition, by assuming that the concept of infinity is understood by students, the teaching of new concepts continues at advanced levels (Özmantar, 2010). Thus, considering the difficulties that the concept of infinity poses both due to itself and in the concepts infinity is related to, it can be said that the concept of infinity is abstract, advanced, difficult and time consuming to learn. Difficulties arising from both the infinity itself and the concepts it is related to indicate that it is important to focus on the learning and teaching of infinity and to examine its place in the curriculum.

\section{Purpose of the Study}

Considering the nature of the concept of infinity, the difficulties arising from the concept and its place in the curriculum, it is seen that there is a gap between the concept and the teaching process of the concept. It is thought that there are question marks on minds during the teaching and learning of the concept of infinity, which has been followed with interest for many years and has been the content of many studies, and research should be done in this context to eliminate these question marks. In this study, it was aimed to examine the place of 
the concept of infinity in the Turkish middle school mathematics curriculum from the perspective of pre-service teachers.

\section{Method(s)}

In the study, qualitative research method was adopted, and the research design of the study was a case study (Yin, 2018). The participants of the study consisted of 61 pre-service mathematics teachers who were studying at a state university in the Marmara region at the time of the study and they were selected with the convenience sampling method. Data were collected in two stages. First, written questionnaire was given to the participants. Then, semi-structured interviews were conducted to determine the opinions of the pre-service teachers about the curriculum and the concept of infinity. The data were analyzed by using descriptive statistics.

\section{Findings and Discussions}

Findings of the study revealed that the preservice teachers associated 30 objectives in the mathematics curriculum with the concept of infinity. The objectives thought to be related to the concept of infinity by the pre-service teachers were included under 17 topics in different grade levels in the learning areas of numbers and operations, algebra, geometry and measurement and probability. Among the objectives, 9 objectives were at the $5^{\text {th }}$ grade level, 7 objectives at the $6^{\text {th }}$ grade level, 6 objectives at the $7^{\text {th }}$ grade level and 5 objectives were at the $8^{\text {th }}$ grade level. The objective "Students can explain line, line segment and ray and represent it by symbol" was the most associated objective with the concept of infinity by the 20 pre-service teachers. 9 objectives in numbers and operations learning area,3 objectives in algebra learning area, 4 objectives in geometry and measurement learning area and 1 objective in probability learning area were associated with infinity by the pre-service teachers. Rational numbers in the numbers and operations learning area, basic geometric concepts and drawings in the geometry and measurement learning area, and inequalities in the algebra learning area have been the topics that were the most associated with the concept of infinity. In the probability learning area, only one pre-service teacher associated 1 objective with infinity. While 17 of the preservice teachers made explanations about the teaching process of the objectives, 17 of them made explanations about solutions of problems related to the objectives. In addition, 18 of the pre-service teachers made explanations related to the category of misconceptions about the concept of infinity and 11 of the pre-service teachers made explanations related to the category of development of ideas about the concept of infinity. To the question "Should the concept of 
infinity be included in the mathematics curriculum ( $5^{\text {th }}-8^{\text {th }}$ grades)?” 46 of the pre-service teachers said yes, 6 of them said no, and 7 of them stated that they are undecided.

\section{Conclusions and Recommendations}

It can be said that the number of objectives associated with the concept of infinity by the pre-service teachers is relatively high. The objectives associated with infinity are distributed in similar numbers across different grade levels. This situation can be an indicator of the fact that there are objectives regarding infinity at each grade level. The objectives which were most associated with infinity by the pre-service teachers belong to the concepts of number sets, patterns, sequence, and irrational numbers, in which students experience difficulties arising from infinity. Because of the necessity to teach the concepts that are prerequisite for teaching of any concept in mathematics lessons (Altun, 2013), it can be thought to focus on the concept of infinity before teaching the specified concepts.

In conclusion, in this study, the fact that infinity is included in the curriculum has been revealed with the objectives determined from the perspective of the pre-service teachers and their explanations. For further research studies, it is recommended that to what extent the determined objectives are related to the concept of infinity can be identified. 